\title{
Development and Communication in trade relations: new synergies in theory and practice
}

\begin{abstract}
This article examines trade relations in Alternative Food Networks as a space where communication practices can prove empowering for rural communities. Drawing on a theory of diverse economies, the article offers an alternative view of the global market, highlighting the social relations that underpin market transactions. These relations are then explored through a case study of a farming community in South India and their interactions with private enterprises in North America and Europe. The findings demonstrate how a dialogical communication process between the two groups can contribute to farmers' well-being beyond economic growth, creating opportunities for more permanent social change.
\end{abstract}

\section{Introduction}

In a recent article published in the Guardian, founder of 'Orange Door Research' Michael Kleinman reminded us that development is not a science but a struggle to try to improve the human condition, albeit without always being able to measure the impact of these efforts. His call for moving beyond interventions that promise to produce measurable results echoes many voices who stress the need for a renewed approach to the role of communication in the field of Communication for Development and Social Change (CDSC). ${ }^{1}$ Following numerous paradigmatic shifts in the field, communication scholars are now pointing to the need for a shift away from the institutional logic that has characterised development communication programmes so far. There are calls for more attention to the appropriation of media and communication practices at the grassroots level; that is, for a recognition that genuine social change is more likely to happen through smaller and self-sustained projects, rather than through institutional efforts that rely on large aid packages and a 'silver bullet' mind set (Hemer and Tufte, 2016; McAnany, 2012; Quarry and Ramírez, 2009; Ramalingam, 2013; Waisbord, 2015).

In response to this need, this article suggests that communication scholars and practitioners can learn from communication practices that underpin everyday relations and experiences and that this can offer a meaningful space for more organic approaches to CDSC. Such a space can be found in the context of market relations where poorer communities are involved in business partnerships with private enterprises. Since the entry into the World Trade Organization of an increasing number of countries from the Global South, the role of the market in development is becoming clearer; and the development prospects of food growers, in particular, are increasingly more dependent on their ability to be market oriented (van de Fliert, 2014). Moreover, as the field of development is gradually moving towards the economic and social innovation field to discover opportunities for social change (McAnany, 2014), market relations merit more attention in relation to the role that communication can play in development and social change through grassroots approaches. This article focuses on market relations that are performed in the context of Alternative Food Networks (AFNs). It proposes that the communication practices that underpin such relations warrant closer investigation with regard to their capacity to empower farming communities. Scholars have already paved the way for the study of businesses and private enterprises in poverty eradication and development. Yet, the communication practices that mediate market transactions remain understudied as is

\footnotetext{
${ }^{1}$ I use the name 'Communication for Development and Social Change' as a term that captures both institutional efforts for development and efforts for permanent social change in people's lives on the ground.
} 
their potential contribution to permanent social change in the lives of marginalised communities.

Drawing on the work of Katherine Gibson and Julie Graham, it is suggested that understanding the role of market relations in development and social change can benefit from recognition of the non-monetary practices that underpin market transactions where communication occurs. To explore such practices in a real-life context, I employ a case study of a community of Fairtrade organic farmers in South India - the Indian Organic Farmers Producer Company Limited (IOFPCL) - and their foreign buyers comprised of a group of small private enterprises. The article is based on an ongoing study and the data was collected through two rounds of focus groups and individual interviews with farmers and officials from IOFPCL in 2014 and 2016. This data was combined with in-depth interviews with five buyers in Europe and North America. The findings demonstrate some of the less visible, yet significant, informal communication processes that connect farmers with the buyers. They reveal the potential for businesses to contribute to development as part of the expected role of private enterprises within the global food market and through everyday practices of communication that happen at a grassroots level. The article concludes with suggestions about how to achieve closer collaborations between CDSC scholars and private enterprise practitioners to discover new opportunities and trajectories for communication practices that can enhance permanent social change in people's lives on the ground.

\section{Markets and development: the need for alternative approaches to economic relations}

In today's market economy, poor communities are perceived as the most disadvantaged, but over the past few decades, aid-giving institutions have had limited impact in helping them to improve their lives (McAnany, 2014: 251). Some of the recently developed efforts to battle with poverty have focused mostly on creating economic opportunities for the poor. In this context, the role of business partnerships in development has been studied primarily in relation to broader global development initiatives to include the world's poorer communities in global markets as well as in relation to Corporate Social Responsibility (CSR) activities. Management scholar C. K. Pahalad has been particularly influential through his vision of an inclusive and creative capitalism where poverty alleviation and social transformation in less developed countries can be supported through their engagement in entrepreneurship (Prahalad, 2009). Such initiatives can ameliorate poverty through market engagement and various constellations of actors and institutions. Commonly used examples include microcredit and the provision of loans to poor borrowers who typically lack security; the so-called 'Bottom of the Pyramid' systems that bring new products and services to consumers in the less developed parts of the world. In these business models, communities in the poorer countries are not positioned as passive receivers of aid; instead, they are recast as agents of their own development (Blowfield and Dolan, 2014; Prahalad, 2009). ${ }^{2}$ There are, however, several shortcomings in these initiatives. Easterly (2008) has criticised them as the work of 'planners' who set big goals and adopt a top-down 'transformational' approach to development, but neglect the complexity of grounded reality. Blowfield and Dolan also argue that the impact of many of these projects is commonly assessed 'in terms of the instrumental value to business rather than to the poor and marginalised' (2014: 35).

An important additional limitation is the emphasis of these projects on the development of innovative products and on income generation and the heavy focus on economic returns such that these initiatives obscure the valuable non-monetary input of market relations. ${ }^{3}$ In the area

\footnotetext{
${ }^{2}$ See Blowfield and Dolan (2014) and McAnany (2014) for a review of cases of businesses and social enterprises involved in innovative projects for social change in developing countries.

${ }^{3}$ Examples of non-monetised contributions have been touched upon in the context of Fairtrade - a point to which I return later.
} 
of agriculture, specifically, the importance of non-monetary relations in market activities has been theorised using the concept of multifunctionality which highlights the range of functions of agriculture in modern society in addition to providing food and fibre. These functions include not only economic growth and development, but also environmental and ecological sustainability as well as social cohesion and rural vitality. The underlying principle of multifunctional agriculture is the multifunctionality of economic activity itself, with its multiple commodity and non-commodity outputs (Cairol, et al, 2009:272; Moon, 2015). The process of multifunctionality is of course subject to the economic and political particularities of different regions. Yet, it is the central idea of multiple functions of economic activity and agriculture that highlights the need and paves the way for a closer examination of the diversity of actors and practices that support and sustain these functions. Amongst these practices are the communication practices that are embedded in business relations and market initiatives on a grassroots level. ${ }^{4}$

Unfolding the significance and impact of these communication practices requires a different approach to the economy and market relations to overcome dominant conceptions of commercial activities as capitalist activities. The work of Katherine Gibson and Julie Graham on the idea of diverse economies is particularly insightful in this case. Gibson-Graham's theory of a 'weak economy' champions a view of global capitalism, not as all-encompassing but as the outcome of many types of economic activities that are often less visible to researchers. For them, the economy is similar to an iceberg where the tip constitutes formal market transactions, wage labour and capitalist enterprises. These are underpinned by submerged non-market transactions and social relations. Although the activities and relations below the waterline are generally hidden from view, the capitalist economy depends on these to function. In essence, the transactions that constitute the economy are connected to 'other-than-capitalist' relations that sustain the iceberg (Gibson- Graham, 2006: 71).

The idea of an economy that rests on the sociability of market relations enables the theory to prompt an exploration of those relations that remain hidden when one looks at the economy only through the prism of capitalism. It also paves the way to explore opportunities for development and social change that reside in everyday relations that sustain market transactions and which undoubtedly are based on dialogue and interpersonal communication. Although Gibson-Graham do not refer to communication practices per se or to how informal economic relations are mediated, they describe alternative, non-monetised practices that would not be possible without communication. ${ }^{5}$ The strength of their theory is that it prompts a consideration of how communication is embedded in these practices. It creates an impetus to pay closer attention to communication that happens at the grassroots less formal level of the economy and which can open up new trajectories for exploring the role of different actors in development and social change.

\section{Alternative Food Networks as diverse economies}

An economic model that sits easily with the theory of diverse economies is offered by the case of Alternative Food Networks (AFNs) which provides a basis for a critique of globalisation and the neoliberal relations that conventional markets are normally associated with (Goodman et al, 2014). But these networks are also seen as hybrids that simultaneously combine capitalist and other-than-capitalist economic logics (Ballamingie and Walker, 2013). Traditionally, AFNs are characterised by relational chains based on transparency and traceability. They rely

\footnotetext{
${ }^{4}$ Prahalad refers to ICTs, but beyond that, the role of communication in the context of the market has not received much attention.

5 '... when a cooperative sets its wage levels, when a food seller adjusts her price for one customer and not another, when a farmer allows gleaners to his fields...some recognition of economic co-implication, interdependency and social connection is actively occurring' (Gibson-Graham, 2006 82-83).
} 
on consumers' willingness to pay a premium price in return for products that have been grown in an environmentally friendly and ethical manner which can also allow farmers to stay in business (Stamm 2008). In theory at least, AFNs represent alternative economic platforms with the capacity for development and social change through re-building relations of care, trust and commitment based on closer proximity and mutual understanding (Kneafsey et al., 2008). For spatially extended networks, in particular, such as Fairtrade networks and supply chains for artisanal foods, their development efficacy is encapsulated by their capacity to re-spatialise market relations and shorten the distance between consumers and producers through the provision of value-laden information (Renting et al. 2003). In this case, development is conceptualised as income generation for food growers, facilitated by higher ecological and social standards and the relevant certification and labelling.

Development also happens through the benefits that farming communities in the South can gain from their relations with intermediaries, such as importers/buyers or coffee roasters. Until now, these benefits have been observed mostly in the context of Fairtrade. For instance, in a study about Fairtrade coffee in Guatemala, Lyon (2006) makes a case for coffee roasters and importers being in close and steady contact with food growers, supporting them to improve their business practices while they also educate them regarding foreign market preferences (Gereffi, 1999; Ronchi 2002). Food growers are also able to build social capital, self-esteem and additional language and computer skills, as well as an increased capacity to participate in their community and deal with local institutions (see Becchetti and Costantino 2005; Imhof and Lee 2007; Poncelet 2005). It is these types of practices that show the potential of market relations to empower poorer communities in more ways than income generation and which deserve scholarly attention since they present opportunities for CDSC to explore new avenues for social change.

\section{Researching communication for development and social change in food networks: a case study of the Indian Organic Farmers Producer Company Limited (IOFPCL)}

An ongoing qualitative exploratory case study is focusing on the Indian Organic Farmers Producer Company Limited (IOFPCL) headquartered in Aluva, Kerala. IOFPCL is a marketing and procurement body that acts as a liaison between organic farmers and foreign buyers with over 600 organic farming shareholders from South India. The company follows cooperative and Fairtrade principles and its main crops, all organic, include black pepper, ginger, turmeric, vanilla, coffee, cocoa, coconut oil and cashew nuts. I focus particularly on the IOFPCL shareholders based in the Wayanad District where Kerala's organic export movement and organic certification institutions have their roots (Thottathill, 2014). The majority of the organic farmers in Wayanad that trade through IOFPCL are members of a cooperative based in Wayanad whose chairman is also a board member in IOFPCL. The case of IOFPCL exemplifies the political and social culture in Kerala that has supported development innovation through years of mobilization, government reforms and educational programmes. It is also the result of the long-term efforts made by food producers, local activists and religious leaders in South India to address the numerous agricultural hardships and distress faced by farmers - mainly due to dependence on cash crops and chemicals - which led to a number of farmer suicides in Wayanad at the beginning of this century. Since then, a number of bodies have been established including the 'Indian Farmers' Movement' (INFAM), the first historically significant certified organic entity, and 'Organic Wayanad', an internal control system that assists farmers with the process of gaining organic certification. Of decisive importance was the establishment of 'Indocert', the first indigenous organic certification body in India that facilitated farmers' introduction to certified organic agriculture and their access to European and North American markets (Thottathill, 2014). 


\section{Data collection and interview design}

The data collection began in the district of Wayanad, Kerala in February 2014. Focus groups with thirty organic farmers were conducted between 17 and 25 February 2014. The interviews were conducted in groups of three or four, depending on the farmers' location and availability. Six groups of four and two groups of three were conducted. Individual interviews were also conducted with two officials, the Chairman of IOFPCL and the Coordinator of Organic Wayanad. The majority of interviews took place in the participants' local language, Malayalam, with the aid of a local interpreter. The second phase of the research included interviews with five of the buyers that collaborate with IOFPCL in Europe and North America. Four of those are small-medium enterprises, wholesalers and retailers. One of the buyers is one of Europe's largest alternative trading organizations. At the time of the interviews, all buyers were certified to comply with organic quality standards, but only four had also gained Fairtrade certification. The interviews were conducted through skype from August 2014 to January 2015.

In September 2016 a second round of six focus groups - four groups of five and two groups of six participants - was conducted in Wayanad. Of the six groups, three involved farmers who were interviewed two years earlier, while the other three were interviewed for the first time. Revisiting the farmers enabled me to observe possible changes in the participants' perceptions and practices that could be linked to their relations and communication with the buyers. I was also able to collect fresh data from those farmers who were interviewed for the first time, but who were also able to observe and comment on any changes or progress that had been made since my first visit.

The interview design was driven by Gibson-Graham's proposition for 'reading for difference rather than dominance' (Gibson-Graham, 2006: 54), which brings into visibility the non-capitalist practices that happen in market relations in the context of AFNs. Hence, the interviews aimed to shed light on their relationships and communication beyond the strictly market exchanges and the possible ways in which these relations contribute to the farmers' growth and development. Interview questions were centred on the methods of communication used by the two groups in their interactions and they also aimed to capture a combination of the participants' subjective viewpoints and objective information about their material and social conditions. This was in order to understand the broader context within which the relations occurred and communication was used and to gage the potential role of these relations and communication practices in the farmers' lives. In fact, it became apparent from early on that the dominant form of communication that underpinned these relations was non-technically mediated interpersonal communication that takes place mostly through the frequent visits of the buyers to Wayanad as well as through email, phone and Skype conversations. The use of communication technologies was rarely mentioned in the interviews, but as the interviews progressed, questions were steered towards exploring and understanding the importance of this type of communication in farmers' lives.

The interview data was coded and analysed using a deductive and inductive process. Following the initial deductive coding under the broad interview topics, inductive coding was employed to reveal key themes and connections between those topics (i.e. whether and how certain aspects of the informal relations appeared to relate to certain types of behaviour). All participants have been anonymised and pseudonyms are used to protect their identity. ${ }^{6}$

\section{Learning through face-to-face communication}

\footnotetext{
${ }^{6}$ For the interviews with the farmers, pseudonyms A, B, C etc. were assigned based on the order with which participants spoke in each group. When more than one group discussion was conducted on the same day, the interviews were numbered. For the interviews with the buyers, the same pseudonyms were used based on the chronological order in which they were interviewed.
} 
The overarching finding was that market exchanges between the two parties are characterised by a mutual effort to establish close relationships and to listen and learn from each other. This is a process that is embedded in and is inseparable from the farmers' efforts to grow their incomes. It is also a process that defies the various technical communication challenges and the cultural and language barriers. In fact, all five buyers commented on the problems they faced in their communication with the farmers' group via email or phone which often led to misunderstandings. As one of the buyers explained, 'When you are not on site, there are often a lot of misunderstandings; you think you have explained things clearly but then realise this was not the case. But these are problems that can be overcome' (Buyer B, September 2, 2014). At the same time, there was an appreciation of the effort that was made by both sides to establish a close relationship. In the words of another buyer, 'When you meet the farmers more than once, then there is better communication, and we are both getting better at understanding each other's needs and requirements' (Buyer C, September 12, 2014).

These relations were made possible thanks to the frequent visits that the buyers made to the farmers and the direct communication they established with them. As the chairman of the cooperative group also explained, 'These are small companies that work without intermediaries. They talk to us and to their customers directly; and they also share their customers' feedback with us directly' (Chairman, February 25, 2014). More importantly, these frequent visits become a learning process for the farmers, enabling them to make choices that can lead to improved market access and opportunities for new economic activity. The buyers' visits allowed the two parties to work together and experiment on different methods for the processing and packaging of the products that, in turn, enables the farmers to learn and improve their practices. One of the buyers explained, 'Initially there were deficiencies with the first orders of spices, but we used different machinery and there was a lot of learning for both of us. In the end, we were able to fix the problems and the outcome was close to perfect' (Buyer A, August 11, 2014). Another buyer also said, 'We often have to spend a lot of time experimenting with the different drying and pulping processes, but we manage to achieve excellent quality' (Buyer E, January 12, 2015).

The frequent visits also became a source of information about product development as well as consumer demand. One of the farmers emphasised the importance of the buyers' regular visits for his own development. He explained:

Some of them make a point of visiting us at least once a year; and every time, I learn something new, whether it is about new ideas for developing products or trends that are working well abroad. These ideas are like a seed that is planted in my head (Farmer A, Group Interview 1, September 10, 2016).

In the first round of interviews, another farmer explained that,

There are certain products of high quality that grow here in Wayanad, like turmeric; but not many farmers were cultivating it. When buyers started asking [for it], we understood there was consumer demand, and it was worth investing in it. We then started selling to local consumers too (Farmer B, Group Interview 1, February 20, 2014).

The frequent visits and close contact between the farmers and these buyers may not lead to big transformations. However, through the communication and interaction that is embedded in the buying and selling process, farmers can find opportunities to make changes that contribute to their own development. These changes happen in a small and incremental way, as farmers gradually grow their export market and their local consumer base. 


\section{Development through the power of 'voice' and the act of listening}

A crucial aspect of the close relations the two groups have developed is the buyers' willingness to listen, hence, providing a platform for farmers to have their voices heard. This is an example of the informal reality that sustains market exchanges and is a less visible aspect of the economy. The issue of voice and listening is becoming more prominent in CDSC studies and, as Tacchi (2011) explains, the act of listening and the notion of voice as something that is valued, rather than simply facilitated, has implications for the analysis of communication and development. However, it remains one of the problematic areas of the development communication business that focuses more on 'telling' than on 'listening' (Quarry and Ramírez, 2009). Attention to voice and the act of listening focuses us on the quality of relationships between speakers and listeners and shifts attention from giving marginalised communities access to technologies and information, to listening to their voices and understanding their information and communication needs. In the case of the collaboration of the Wayanadan farmers with their buyers, their close relationship provides farmers with a 'resource' with which to express their views and get results in two different but equally important ways: by facilitating a farmers' discussion that leads to new decisions relating to product promotion and the farmers' representation to the foreign consumers; and by nurturing their confidence in ways that may bring more permanent change.

\section{Promotion of product biographies and farmers' representation}

Communication, voice and listening allows people to participate in decision making across social, economic, cultural and political spheres by enabling them to facilitate their own discussions that can lead to their own plans of action (Lister, 2004; Quarry and Ramirez, 2009; Tacchi, 2011). For the farmers in Wayanad, the relationships and face-to-face communication with the buyers offer a space for them to discuss aspects of their work that have led to specific decisions about the marketing and promotion of their products.

During the interviews the farmers described some of the unique qualities of their products. One of them explained: 'The colour and the composition of the soil, in particular, are very crucial in giving the special flavour and taste to the products' (Farmer B, Group Interview 1, February 17, 2014). Another one added: 'There is a lot of greenery compared to other parts of Kerala, there are a lot of mountains, and this makes a big difference' (Farmer B, Group Interview 2, February 17, 2014). The medicinal plants growing in the area are also believed to affect the taste of the products. Another participant explained: 'There are a lot of weeds growing in my farm with medicinal properties. As their seeds feed the soil, their properties are transferred to the bananas that are growing next to these weeds' (Farmer B, Group Interview 2, February 20 2014). They also referred to their use of natural processes such as the use of local medicinal plants as fertilisers. These unique properties have attracted the attention of the buyers who have initiated a conversation about the value and promotion of the product biographies to local and foreign consumers. One of the European buyers explained, 'We have an ongoing discussion about how best to promote these qualities and the farmers' labour to the consumers; either through visual evidence or even by inviting some of the customers to visit the farmers here' (Buyer B, September 2, 2014). The same buyer also expressed his willingness to engage more with the farmers in order to better understand their work. In a follow-up interview two years later he added:

We visit the group more often now and organise tasting and cupping events so that we both understand each other's needs and offer each other new knowledge. We want to scratch beneath the surface, learn from their expertise and traditional methods; and we want to invite people from our part of the world to come and experience this life (Buyer B, May 27, 2016). 
Another of the group's European partners also explained that he was involved in an ongoing conversation with the group's Chairman to promote the famous Tellicherry pepper which is currently threatened with extinction. He said,

We have to be involved in a constant dialogue, for the benefit of both sides. My background and experience is in marketing, so I can share my ideas with them. But, the technical side of the pepper production and processing is their expertise. I'm learning from them details, such as the importance of the garbling process, which I can use to promote and sell the pepper to my customers (Buyer E, January 12, 2015).

The significance of these conversations lies in the actions and decisions that farmers had taken as a result of engaging in direct communication with these buyers. During the second round of interviews with the farmers and with the coordinator of the farmers' internal control system, they talked about the regular training workshops they were organising at the farmers' facilities focusing on marketing. Some of the farmers admitted that they had changed the way they were promoting their products, making a conscious effort to highlight the labour and provenance, a strategy that also secured some new partnerships with European buyers. One of them explained:

I am now thinking more about the special methods I use for farming the pepper...it struck me how I could talk more about these, and I even secured a new buyer from Belgium, for single estate pepper (Farmer A, Group Interview 1, September 12, 2016).

It may appear that buyers are telling farmers what to do which would resemble a form of modern colonialism and not all the collaborations have worked out well for the farmers. They were, in fact, dropped by one of their first buyers in Europe when they failed to comply with their expectations. During an interview with the representative of the specific company, she explained that they had offered regular training and had also pre-financed the products. However, problems with the weather and harvesting meant that they did not receive the quantity they asked for and ended the partnership (Interview with Buyer D, November 13, 2014). It is important to recognise that not all relationships prove to be beneficial. At the same time, it may be unreasonable to expect symmetric relationships in a context where the economic power resides with the buyers. Moreover, the findings show how, even in these asymmetric relationships, small and communicative enterprises can encourage more horizontal communication that informs farmers about marketing opportunities and allows them to organise their own internal discussions and training sessions before they take further action. These are examples of the small-scale changes that farmers are initiating, but which have the potential to lead to longer-term solutions as they participate actively in discussions with their peers and plan for the future. Moreover, buyers are the proxies that connect the farmers with consumers and such conversations enable farmers to be more actively involved in decisions about how they will be represented to consumers in the North. This is another way in which the communication between the two groups offers a space for voice and self-expression.

\section{Communication and confidence building in an adverse social environment}

One of the least visible aspects of the relations that underpin market transactions in the global food market is the sense of self-esteem and confidence that farming communities can gain through their close contact and communication with other actors. Once again, it is the 'listening' side of this communication that proves to be most empowering for the farmers in Wayanad because they find motivation in the frequent visits of the buyers and the attention and 
appreciation they receive from them. A dominant theme that emerged during both rounds of interviews with the farmers concerned the lack of respect they received from the local community and the state. As all the groups invariably explained, people in Kerala had a skewed image of farmers. According to one of the farmers,

People think we are extremely poor and miserable. Even the local businesses and the church promote these images to the communities, and the people from the church come with charity handouts; but no one takes them because they do not need them (Farmer A, Group Interview 2, September, 12 2016).

These perceptions are reinforced by the lack of respect and recognition from official bodies such as the local government or the banks. One of the participants said, 'We work so hard to provide food to everyone, but we never get the same respect as white-collar workers' (Farmer, B, Group Interview 2, September 12, 2016). To make things worse, being an organic farmer exacerbates the social pressure. Organic farmers are often marginalised and even ridiculed by their peers for cultivating multi crops in a natural way, instead of opting for the more profitable non-organic monocrop production. For many farmers these societal perceptions and lack of recognition poses serious threats to the sustainability of the locale as it drives young people away from organic agriculture. Some of them admitted that despite their own passion for cultivating the land and feeding the world, they were sceptical about encouraging their children to follow their path. They explained that,

Government officials and banks do not think highly of the farmers, they do not take us seriously, and that is why the young people do not want to get involved. Why should we encourage our kids to become farmers if they are going to have the same treatment from the society like we did?' (Farmer A, Group Interview 1, September 8, 2016).

Against this backdrop, many of them admitted that changing the farmers' image and improving their social status is paramount for the younger generation to become involved in farming and remain in Wayanad; and it became apparent that the appreciation they receive from the foreign buyers gives them a confidence boost and the motivation to work towards achieving this change. This was reflected in the words of a farmer, who said,

When the foreigners come to visit, this makes me feel important...they are coming from so far away to see my farm and learn about my farming techniques, and they tell me they like my methods. They are quite inquisitive, so I'm also doing my best to improve the quality of my products (Farmer C, Group Interview 1, February 18, 2014).

Another farmer who also focused on medicinal Ayurvedic plants explained how the frequent visits of the foreign buyers were a valuable source of motivation for him:

It makes me really happy to see people visiting me from abroad and listening to what I have to say and offer. It drives me to work harder, and I'm gradually building networks and educating people - including the tribal farmers - about the benefits of these plants (Farmer C, Group Interview, February 25, 2014).

When I visited him again two years later, he explained that he was having more foreign visitors, including Ayurvedic doctors, and was receiving more appreciation from the local community as well. 
As Quarry and Ramirez (2009) explain, 'listening is the function of communication that nurtures our self-awareness and sense of confidence, the one that helps us change our situation in our own terms' (p.20). The significance of the buyers' visits and willingness to listen was evident in the changes that farmers achieve on an individual and collective level. During my second visit, two groups of farmers had taken steps to promote their natural farming practices to the local public through meetings organised by the local community. They were also considering creating their own short videos about their farming techniques to share with nonorganic farmers and with consumers. One of the farmers said, 'Initially the community may make fun of us, but such videos can actually help us work more closely with each other' (Farmer C, Group Interview 1, September 14, 2016). A group of farmers within the cooperative had also set up their own producer company for the procurement and marketing of tea, a move that seemed to be paying off, especially since the children of two of the farmers, both graduates and in their 20s, had decided to get involved. This is the type of social network activation that promotes long-lasting transformations toward social justice at individual and community levels. More importantly, this was encouraged through the less visible, more informal and nonmonetary relations that inhabit market transactions and through which a different aspect of businesses' development efficacy can be observed.

\section{Conclusion}

As with any case study, the findings presented in this article are not generalizable. Yet, by shifting attention away from dominant conceptions of development as income growth, the study sheds light on the non-monetised impact that market relations can have on the development of poorer communities through less visible practices such as interpersonal communication. Although the ultimate benefits for the Wayanadan farming community are economic and translate into new partnerships with foreign buyers and the development of their local market, the analysis highlights the empowering aspect of the process through which these economic returns happen and in which communication is a key component. Through the ethical philosophy and behaviour of individual buyers and the acts of listening, a cyclical learning process is activated whereby the farmers are able to feed their knowledge to these intermediaries and also have a voice in how they are represented to their respective consumers. This has been shown to make a significant contribution to their well-being and sense of selfefficacy as they fight to protect their biodiversity and secure a sustainable future against the local society's rigid and prejudicial structures. Moreover, the gratification that farmers appear to gain from cultivating the land, feeding the world with good quality products and protecting the environment and from being appreciated by the buyers is evidence of the multidimensional nature of well-being and development. It is also a reminder that economic growth is not the only indicator for measuring improvement (Asiedu, 2011).

Gibson-Graham's theory of diverse economies offers a valuable lens through which to position and explore the role of communication in market relations as integral to the less visible and informal relations that sustain the economy. Despite being less measurable by conventional indices, such relations have been shown to benefit the farming communities of Wayanad in subtle, yet significant, ways, beyond market access. The theory of diverse economies also demonstrates that engaging with new theoretical frameworks can open up new avenues for research inquiry. By offering an alternative approach to the economy, the theory generates opportunities for CDSC to develop a new discourse so that future research can demonstrate the importance of communication in economic development.

At the same time, by bringing to the fore the importance of interpersonal and dialogic communication in the relations that sustain the capitalist economy, the findings offer further conceptual validity to the idea of diverse economies. They reveal the diversity and heterogeneity of practices that are packaged together to create the global food economy and 
which serve to reframe food economies as constituted by a range of rationales and social values. As such, this case study provides a basis for encouraging research that is driven by reading for difference and working with a 'weak theory' approach as well as a thick description of communication practices. Such an approach resists the pull towards strong theories of behavioural change and directs attention to nuances, affects and multiple codes of meaning (Gibson-Graham, 2008; Sarmiento, 2017).

Moreover, the close relations and communication practices embedded in the business activities of the two groups highlight business participation in development, not as a development agent, but as part of the expected role of private enterprises within the global food market. This confirms that development opportunities exist in market activities that are not confined to institutional approaches and programmes that strive to deliver specific developmental outcomes. Further study of CDSC, looking at market activities and relations can also create opportunities to: a) focus more closely on everyday practices of communication on a grassroots level, and b) move beyond institutional efforts relying on large aid packages. This is in line with the need for more modest approaches to development and interventions that happen in a modest and incremental manner (Easterly 2008).

For scholars and practitioners in CDSC, investing more time to engage with actors that are involved with poorer communities to understand the way that the small businesses work with the farmers in Wayanad can yield opportunities for small marginal projects that can gradually grow as more people participate. It is also likely to provide a more nuanced understanding of the role of actors in supporting communities to develop new patterns of behaviour and attain improved economic, social and political well-being. In the case study considered in this article, AFNs offered a platform to demonstrate different types of partnerships through which development and social change can be achieved, but similar opportunities are likely to be discovered in other areas of market activity where CDSC research and practice could make its mark on the structures of the global market.

Last but not least, it is through such grassroots activities that the significance of interpersonal communication can also be acknowledged. This case study drew attention to the crucial role that interpersonal and dialogic communication plays in development and social change, but which is also too often taken for granted (Quarry and Ramirez, 2009:31). Interpersonal communication can enable meaningful knowledge generation and exchange, skill development and the establishment of a platform for collective decision making and action (Rodriquez, 2011; Thomas and van de Fliert, 2014). This was shown in the case of Wayanad where the buyers' willingness to listen to and learn from the farmers' experience empowered farmers through confidence building and enhanced self-esteem that was then channelled into actions and decisions that led to more permanent change. Examples like this demonstrate that what matters is not just the availability of information for marginalised groups to facilitate change, but also the quality of relationships between speakers and listeners. Development and social change require recognition and 'listening' to alternative voices which is as important as the process of 'speaking' (Couldry, 2010; Tacchi, 2011). As McAnany (2012) asserts, communication is not sufficiently prioritised by development agencies or even by world leaders and there is a need to place communication centrally within the work of development and social change (p.6). Investing more research and resources in exploring the role of interpersonal communication and facilitating dialogic communication among different actors can be one of the ways forward.

\section{References}

Asiedu, C. (2011) 'Information communication technologies for gender and development' Information, Communication \& Society pp. 1-31 
Ballamingie, P., and Walker, S. (2013). Field of dreams: Just food's proposal to create a community food and sustainable agriculture hub in Ottawa, Ontario. Local Environment: The International Journal of Justice and Sustainability, 18(5), 529-542.

Becchetti, L., and Costantino, M. (2005). The effects of Fair Trade on marginalised producers: an impact analysis on Kenyan farmers. Rome, Italy: University of Vergata.

Blowfield, M. and Dolan, C.S. (2014). Business as a development agent: evidence of possibility and improbability. Third World Quarterly. 35(1), 22-42

Cairol, D., Coudel, E., Knickel, K., Caron, P. \& Kröger, M. (2009). Multifunctionality of Agriculture and Rural Areas as Reflected in Policies: The Importance and Relevance of the Territorial View. Journal of Environmental Policy and Planning. 11(4): 269-289

Couldry, N. (2010). Why voice matters: Culture and politics after neoliberalism. London, UK: SAGE

Easterly, W. (2006). The White Man's Burden: Why the West's efforts to aid the rest have done so much ill and so little good. Oxford: Oxford University Press.

Gereffi, G., (1999). International trade and industrial upgrading in the apparel commodity chain. Journal of international economics, 48 (1), 37-70.

Gibson-Graham, J.K. (2008) Diverse economies: Performative practices for other worlds. Progress in Human Geography 32(5): 613-632.

Gibson-Graham, J.K. (2006) A Postcapitalist Politics, Mineapolis; London: University of Minnesota Press.

Goodman, D., DuPuis, M.E., and Goodman, M.K., (2014). Alternative food networks: knowledge, practice and politics. New York: Routledge.

Hemer, O. and Tufte, T. (2016). Introduction. Why Voice and Matter Matter. In: O. Hemer and T. Tufte (Eds.) Voice and Matter: Communication, Development and the Cultural Return. Göteborg, Sweden Nordicom. pp.11-25

Imhof, S., and Lee, A. (2007). Assessing the potential of Fair Trade for poverty reduction and conflict prevention: a case study of Bolivian coffee producers. Basel, Switzerland: University of Basel.

Kleinman, M. (2017). Development is not a science and cannot be measured. That is not a bad thing. The Guardian available at: https://www.theguardian.com/global-developmentprofessionals-network/2017/jun/01/development-is-not-a-science-and-cannot-be-measuredthat-is-not-a-bad-thing?CMP (accessed 5/6/2017)

Kneafsey, M., Cox, R., Holloway, L., Dowler, E., Venn, L., and Tuomainen, H. (2008). Reconnecting Consumers, Producers and Food. Oxford: Berg.

Lyon, S., (2006). Evaluating fair trade consumption: politics, defetishization and producer participation. International journal of consumer studies, 30 (5), 452-464.

McAnany, E. G. (2014). Economics and Communication for Development and Social Change. In K.G. Wilkins, T. Tufte and R. Obregon (Eds.) Handbook of Development Communication and Social Change. Chichester, UK: John Wiley \& Sons Ltd. Pp.242-258

McAnany, E. G.(2012). Saving the world: a brief history of communication for development and social change. Urbana University of Illinois Press. Land Use Policy. 49: 252-263

Moon, W. (2015). Conceptualising multifunctional agriculture from a global perspective: Implications for governing agricultural trade in the post-Doha Round era

Poncelet, M. (2005). A fair and sustainable trade, between market and solidarity: diagnosis and prospects. Liege, Belgium: University of Liege.

Prahalad, C. K. (2009). The fortune at the bottom of the pyramid; eradicating poverty through profits. New Jersey: Pearson FT Press

Quarry, W. and Ramírez, R. (2009). Communication for another development: Listening before telling. NewYork, NY: Zed Books. 
Ramalingam, B. (2013). Aid on the Edge of Chaos: Rethinking International Cooperation in a Complex World. Oxford: Oxford University Press

Renting, H., Marsden, T., and Banks, J. (2003). Understanding alternative food networks: exploring the role of short supply chains in rural development. Environment and Planning A, 35(3), 393-411.

Rodriquez, C. (2011). Citizen's media against armed conflict: Disrupting violence in Columbia. Minneapolis: University of Minnesota Press.

Ronchi, L. (2002). The impact of Fair Trade on producers and their organizations: a case study with Coocafé in Costa Rica. Poverty Research Unit. University of Sussex, Brighton.

Sarmiento, E. R. (2017). Synergies in alternative food network research: embodiment, diverse economies, and more-than-human food geographies. Agriculture and Human Values 34(2):485-497

Servaes, J., (2013). Introduction: the Kaleidoscope of text and context in communication. In: J. Servaes, ed. Sustainability, participation and culture in communication: theory andpraxis. Bristol: Intellect, pp.1-24.

Stamm, A. (2008). Agribusiness and poverty reduction: what can be learned from the value chain approach? In: C. Stringer and R. Le Heron, (Eds). Agri-food commodity chains and globalising networks. Hampshire: Ashgate, 23-34.

Tacchi, J. (2011). Open content creation: The issue of voice and the challenges of listening, New Media and Society, 14(4), 652-668.

Thomas, P. N. and van de Fliert, E. (2014). Interrogating the Theory and Practice of Communication for Social Change: The Basis For a Renewal, NY: Palgrave, McMillan

Thomas, P. N. (2011). Negotiating communication rights: Case studies from India. London, England: Sage.

Thottathill, S.E., (2014). India's organic farming revolution: what it means for our global food system. Iowa City: University of Iowa Press.

Waisbord, S. (2015).Three challenges for communication and global social change.

Communication Theory, 25(2), 144-165. 